\title{
ANALISIS FAKTOR-FAKTOR YANG MEMPENGARUHI TINGKAT KEPATUHAN PAJAK WAJIB PAJAK BADAN PADA PERUSAHAAN INDUSTRI MANUFAKTUR DI DAERAH ISTIMEWA YOGYAKARTA
}

Didik Irawan

Alia Ariesanti

\begin{abstract}
The purpose of the research is to analyze the behavior of tax compliance of corporate taxpayers, particularly large industrial manufacturing company that exists through out Daerah Istimewa Yogyakarta, represented by professional tax who work at the company. The results of this study indicate that: (1) the strength or weakness of a professional tax attitude does not affect the level of tax compliance in a corporate entity, (2) subjective norm has no effect on the level of corporate tax compliance, (3) strong or weak moral obligation of professional tax does not affect the level of tax compliance in a corporate entity, (4) the strength or weakness of a professional tax intention to behave not affect the level of tax compliance in a corporate entity, (5) the company 's financial condition does not affect the level of corporate tax compliance, (6) large or a small facility of company where professional tax work does not affect the level of tax compliance from a corporate entity, (7) organizational climate where professional tax work affects the level of tax compliance from a corporate entity. This study also represents that professional tax do not greatly affect the level of tax compliance in the corporate taxpayers large manufacturing company in Daerah Istimewa Yogyakarta.
\end{abstract}

Keywords: Professional tax, attitude, subjective norm, moral obligation, intention to behave, the financial condition of the company, the company's facilities, organizational climate, corporate tax compliance.

\section{PENDAHULUAN}

Pembangunan nasional harus dilakukan pemerintah Indonesia secara terusmenerus dan berkesinambungan. Tujuan utama dari pembangunan nasional adalah untuk meningkatkan kesejahteraan rakyat. Sebagai langkah nyata untuk merealisasikan tujuan tersebut, pemerintah sangat perlu mengusahakan berbagai sumber pendapatan guna membiayai pembangunan nasional. Salah satu langkah yang dipilih pemerintah adalah menggalakkan penerimaan negara melalui sektor perpajakan. Pajak dianggap sebagai suatu kewajiban menyerahkan sebagian harta kekayaan ke kas negara disebabkan suatu keadaan, kejadian dan perbuatan yang memberikan kedudukan tertentu, tetapi bukan sebagai hukuman, menurut peraturan 
yang ditetapkan pemerintah serta dapat dipaksakan, tetapi tidak ada jasa timbal balik dari negara secara langsung, untuk memelihara kesejahteraan umum (Brotodiharjo, 1993:2).

Sebagai upaya untuk meningkatkan penerimaan negara dari sektor pajak, maka langkah pemerintah dimulai dengan melakukan reformasi perpajakan secara menyeluruh pada tahun 1983. Sejak itulah Indonesia menganut sistem self assessment. Self assessment adalah suatu sistem pemungutan pajak yang memberikan wewenang kepada wajib pajak untuk menghitung, memperhitungkan, membayar dan melaporkan sendiri besarnya pajak terutang. Sehingga sistem administrasi dapat lebih rapi, terkendali, sederhana dan mudah untuk dipahami.

Sistem self assessment diharapkan dapat menciptakan kondisi yang membentuk kepatuhan pajak secara sukarela dari masyarakat. Akan tetapi menurut penelitian Mustikasari (2007) mengatakan bahwa tingkat kepatuhan pajak di Indonesia masih rendah, hal ini tercermin dari angka tax ratio (perbandingan antara jumlah penerimaan pajak dengan produk domestik bruto setiap tahun) dan tax gap (kesenjangan antara penerimaan pajak yang seharusnya terhimpun dengan realisasi penerimaan pajak yang terkumpul setiap tahun).

Menurut Rachmany (2012) tax ratio Indonesia tahun 2010 hanya 11,3\% dan tahun 2011 adalah 12,3\%. Tax ratio Indonesia termasuk paling rendah apabila dibandingkan dengan Amerika Serikat (26,6\%), Australia (28,9\%), Austria $(42,4 \%)$, Belanda $(38,8 \%)$, Inggris $(35,7 \%)$ dan Jepang $(28 \%)$. Perlu ditumbuhkan terus-menerus kesadaran dan kepatuhan masyarakat wajib pajak guna memenuhi kewajibannya sehingga target pajak tercapai. Di tahun 2012, Direktorat Jenderal Pajak telah menyiapkan beberapa langkah untuk mengamankan target penerimaan pajak, di antaranya (Rachmany, 2012):

1. Penyempurnaan sistem administrasi perpajakan di sektor PPN;

2. Pengawasan secara lebih intensif pada sektor usaha tertentu yang memberikan kontribusi signifikan terhadap penerimaan perpajakan;

3. Pembinaan dan pemberian fasilitas perpajakan kepada sektor Usaha Mikro, Kecil, dan Menengah (UMKM);

4. Peningkatan penegakan hukum di bidang perpajakan dan penyempurnaan 
Sistem Piutang Pajak secara online;

5. Pelaksanaan program Sensus Pajak Nasional (SPN) yang lebih terencana, terarah, dan terukur;

6. Peningkatan kualitas sumberdaya manusia (SDM) seperti: account representative (AR), Pemeriksa Pajak, dan Juru Sita;

7. Penyempurnaan sistem pengendalian internal melalui peningkatan fungsi kepatuhan internal, implementasi nilai-nilai Kementerian Keuangan, dan peningkatan efektivitas whistleblowing system.

Guna mendukung keefektifan penerapan self assessment system, perlu ditumbuhkan secara terus-menerus kepatuhan wajib pajak untuk memenuhi kewajiban pajak sesuai dengan ketentuan yang berlaku. Mengingat kepatuhan merupakan faktor penting penerapan self assessment system dalam peningkatan penerimaan pajak, maka perlu secara intensif dikaji tentang faktor-faktor yang mempengaruhi kepatuhan wajib pajak, khususnya wajib pajak badan.

Kepatuhan pajak (tax compliance) merupakan keadaan wajib pajak yang mempunyai kesediaan untuk mematuhi peraturan perpajakan serta melaporkan seluruh penghasilannya dengan benar, jujur dan akurat. Konsep kepatuhan ini sesuai dengan pendapat Harinurdin (2009), bahwa kondisi ideal kepatuhan pajak didefinisikan sebagai keadaan suatu wajib pajak yang memenuhi semua kewajiban perpajakannya dan melaksanakan hak perpajakannya dalam bentuk formal dan kepatuhan material.

Terkait dengan topik penelitian yang banyak dilakukan oleh peneliti sebelumnya dalam bidang perpajakan, penelitian ini merupakan replikasi dari penelitian Harinurdin (2009). Penelitian ini tetap menggunakan variabel yang sama dari penelitian sebelumnya, yaitu niat berperilaku, kondisi keuangan perusahaan, fasilitas perusahaan dan iklim organisasi. Perbedaan dengan penelitian terdahulu, penelitian ini menambah tiga variabel baru pembentuk niat berperilaku yaitu sikap, norma subjektif, dan kewajiban moral. Niat berperilaku ditentukan oleh 3 faktor penentu, yaitu behavioral beliefs, normative beliefs, dan control beliefs. Secara berurutan, behavioral beliefs menghasilkan sikap dan niat terhadap perilaku positif atau negatif, normative beliefs menghasilkan tekanan sosial yang dipersepsikan dan 
control beliefs menghasilkan kontrol perilaku yang dipersepsikan (Ajzen, 2002).

\section{TINJAUAN PUSTAKA DAN PENGEMBANGAN HIPOTESIS}

\section{Sikap}

Sikap bukan perilaku, tetapi kecenderungan untuk berperilaku dengan cara tertentu terhadap objek sikap. Seseorang yang mengapresiasi objek sikap memiliki kecenderungan akan melakukan tindakan tertentu terhadap objek sikap, dapat berupa dukungan atau penolakan. Tax professional yang memberi dukungan (bersikap positif) terhadap tindakan kepatuhan pajak akan memiliki kecenderungan untuk melakukan kepatuhan pajak. Sebaliknya, tax professional yang melakukan penolakan (bertindak negatif) terhadap tindakan kepatuhan pajak, maka tax professional tersebut akan cenderung melakukan tindakan ketidakpatuhan pajak. Hipotesis penelitian yang diajukan adalah:

$\mathrm{H}_{1}$ : Ada pengaruh sikap tax professional terhadap kepatuhan pajak wajib pajak badan.

\section{Norma Subjektif}

Norma subjektif dari tax professional dapat terbentuk dari kondisi sosial dan lingkungan sekitar. Seorang individu akan melakukan tindakan-tindakan seperti yang diharapkan oleh orang-orang yang penting bagi dirinya. Apabila orang-orang yang penting tersebut bersikap positif terhadap pajak, maka tax professional akan cenderung melakukan tindakan kepatuhan pajak. Begitu pula sebaliknya, apabila orang-orang yang dianggap penting bersikap negatif terhadap pajak, maka tax professional juga akan memiliki kecenderungan untuk tidak patuh terhadap pajak. Hipotesis penelitian yang diajukan adalah:

$\mathrm{H}_{2}$ : Ada pengaruh norma subjektif tax professional terhadap kepatuhan pajak wajib pajak badan.

\section{Kewajiban Moral}

Kewajiban moral berasal dari dalam diri sendiri. Kewajiban moral yang dimiliki seseorang kemungkinan berbeda dengan orang lain. Tax professional yang merasa memiliki kewajiban moral cenderung akan bersikap positif terhadap 
kepatuhan pajak. Sebaliknya, tax professional yang melaksanakan pekerjaannya tanpa menghiraukan sisi moral, cenderung akan bersikap negatif dan asal-asalan terhadap kepatuhan pajak. Hipotesis yang diajukan dalam penelitian ini adalah:

$\mathrm{H}_{3}$ : Ada pengaruh kewajiban moral tax professional terhadap kepatuhan pajak wajib pajak badan.

\section{Niat Berperilaku}

Niat merupakan kecenderungan untuk melakukan suatu tindakan tertentu. Niat juga sangat berhubungan dengan motivasi, yaitu dorongan yang muncul dari dalam diri seseorang untuk melakukan tindakan tertentu. Niat yang baik akan memunculkan motivasi untuk berbuat baik. Perbuatan atau tindakan yang baik akan menghasilkan sesuatu yang baik pula. Jika hal ini dilakukan terus-menerus akan menjadi kebiasaan yang baik, begitu pula sebaliknya.

Niat tax professional memberikan motivasi bagi tax professional untuk melakukan suatu tindakan terhadap kewajiban pajak. Apabila tax professional memiliki motivasi yang baik, bahwa memenuhi kewajiban pajak akan memberikan banyak keuntungan, maka tax professional akan memiliki niat positif terhadap kepatuhan pajak. Sebaliknya, apabila tax professional memiliki pendapat bahwa membayar pajak tidak ada gunanya dan bukan merupakan kewajiban, maka tax professional akan bersikap negatif terhadap kepatuhan pajak. Berdasarkan uraian tersebut, maka hipotesis yang diajukan adalah:

$\mathrm{H}_{4}$ : Ada pengaruh niat berperilaku tax professional terhadap kepatuhan pajak wajib pajak badan.

\section{Kondisi Keuangan Perusahaan}

Kondisi keuangan perusahaan merupakan kemampuan keuangan perusahaan untuk melakukan aktivitas perusahaan dan mempertahankan keberlangsungan perusahaan. Semakin baik kondisi keuangan perusahaan, akan memberi sinyal positif kepada seluruh staf dan karyawan perusahaan, termasuk tax professional. Apabila perusahaan memiliki kondisi keuangan yang buruk, secara tidak langsung akan menimbulkan tindakan negatif dari staf dan karyawan perusahaan tersebut, termasuk tindakan untuk melakukan ketidakpatuhan pajak. Hipotesis yang akan 
diuji dalam penelitian ini adalah:

$\mathrm{H}_{5}$ : Ada pengaruh kondisi keuangan perusahaan terhadap kepatuhan pajak wajib pajak badan.

\section{Fasilitas Perusahaan}

Fasilitas yang diberikan oleh perusahaan, diharapkan dapat menjadi pemicu tax professional agar memaksimalkan kemampuannya dalam menyajikan semua data yang diperlukan perusahaan untuk mengambil keputusan pajak. Adanya fasilitas perusahaan yang memadai akan mengurangi ketidakpastian validitas data yang disajikan oleh tax professional.

Ketika perusahaan memberikan fasilitas yang memadai bagi tax professional, maka ketidakpastian yang dihadapi tax professional hanya akan berkaitan dengan aturan perpajakan yang berlaku. Hipotesis penelitian yang diajukan dalam penelitian ini adalah:

H6: Ada pengaruh fasilitas perusahaan terhadap kepatuhan pajak wajib pajak badan.

\section{Iklim Organisasi}

Perilaku individu dipengaruhi oleh lingkungan tempat individu tersebut berada. Diduga, perilaku individu dalam melakukan tindakan tertentu dipengaruhi salah satunya oleh iklim organisasi. Iklim organisasi merupakan persepsi bersama dalam menentukan kebijakan organisasi.

Iklim organisasi yang positif diharapkan akan mendukung tax professional untuk melakukan kepatuhan pajak. Sebaliknya, iklim organisasi yang negatif akan mendorong tax professional berperilaku tidak patuh. Hipotesis penelitian yang diajukan adalah:

$\mathrm{H}_{7}$ : Ada pengaruh iklim organisasi terhadap kepatuhan pajak wajib pajak badan.

\section{METODA PENELITIAN}

\section{Populasi dan Sampel}

Perusahaan besar dipilih karena pada umumnya perusahaan besar memiliki sistem informasi akuntansi formal yang memungkinkan tax professional menyusun pelaporan pajak badannya (Bouwens dan Abernethy, 2000 dalam Mustikasari, 
2007). Daftar nama perusahaan manufaktur diperoleh dari Dinas Perindustrian, Perdagangan, Koperasi \& UMKM DIY dan Badan Kerjasama \& Penanaman Modal DIY. Teknik pengambilan sampel dengan metoda simple random sampling, sedangkan untuk menentukan jumlah sampel dengan mempertimbangkan kriteriakriteria sebagai berikut (Hendry, 2012):

1. Menurut Gay dan Diehl (1992), jika penelitiannya korelasional, sampel minimumnya adalah 30 subjek.

2. Menurut Roscoe (1975), ukuran sampel lebih dari 30 dan kurang dari 500 adalah tepat untuk kebanyakan penelitian

3. Menurut Frankel dan Wallen (1993:92), penelitian korelasional sebanyak 50 responden.

Metoda pengumpulan data yang digunakan dalam penelitian ini adalah metoda survei dengan menggunakan bantuan kuesioner. Kuesioner penelitian diberikan langsung kepada tax professional perusahaan atau diberikan langsung kepada bagian umum (persuratan) perusahaan dan kemudian akan memberikannya kepada tax professional perusahaan yang disebut data primer.

\section{Definisi Operasional Variabel}

\section{Sikap}

Sikap adalah bentuk evaluasi atau reaksi dari seseorang. Reaksi seseorang terhadap suatu objek dapat berupa dukungan atau penolakan. Sikap tax professional sangat beragam dalam melaksanakan tugasnya. Aspek keyakinan sangat diperlukan oleh tax professional dalam menyelesaikan tugasnya. Oleh karena itu, pernyataanpernyataan yang diukur untuk variabel sikap ini, antara lain mengenai seberapa besar keyakinan taxprofessional dalam mengambil keputusan dan mengenai tingkat harapan terhadap kepatuhan pajak.

\section{Norma Subjektif}

Norma subjektif merupakan kekuatan pandangan orang-orang penting di sekitar tax professional terhadap perilaku tax professional terhadap kepatuhan pajak. Seseorang dapat dipengaruhi atau tidaknya tergantung kepada kekuatan diri sendiri dalam menghadapi orang-orang penting disekitarnya. Indikator yang diukur 
antara lain keyakinan dari tax professional berdasarkan norma perpajakan yang berlaku dan motivasi untuk mematuhi norma perpajakan.

\section{Kewajiban Moral}

Kewajiban moral satu orang dengan yang lain berbeda, begitu pula dengan kewajiban moral yang dimiliki tax professional. Semua tergantung dari persepsi individu masing-masing mengenai kepatuhan pajak. Pernyataan yang diajukan berkaitan dengan persepsi pribadi mengenai tugas dan kewajibannya.

\section{Niat Berperilaku}

Niat adalah kecenderungan dan keputusan tax professional untuk melakukan perilaku kepatuhan pajak atau ketidakpatuhan pajak. Pengukuran variabel ini, responden akan diminta pendapatnya mengenai kecenderungan dan keputusan terhadap ketentuan perpajakan.

\section{Kondisi Keuangan Perusahaan}

Persepsi mengenai kondisi keuangan perusahaan adalah persepsi tax professional atas kemampuan keuangan perusahaan untuk beraktivitas. Pengukuran variabel yang digunakan berkaitan dengan kondisi arus kas tahun terakhir dan kondisi laba sebelum pajak tahun terakhir.

\section{Fasilitas Perusahaan}

Persepsi tentang fasilitas perusahaan adalah persepsi tax professional mengenai seluruh sumber daya yang dimiliki perusahaan tempat tax professional bekerja, termasuk tersedianya informasi keuangan dan operasi perusahaan. Pengukuran variabel ini dengan menggunakan pernyataan-pernyataan mengenai kelengkapan administrasi yang mendukung pelaporan pajak.

\section{Iklim Organisasi}

Iklim organisasi merupakan persepsi tax professional dalam mengapresiasi kebijakan, praktik dan prosedur organisasi. Indikator yang digunakan adalah wewenang, imbalan, dukungan, risiko dan kewajiban. 


\section{Kepatuhan Pajak Badan}

Kepatuhan pajak (tax compliance) merupakan keadaan wajib pajak yang mempunyai kesediaan untuk mematuhi peraturan perpajakan serta melaporkan seluruh penghasilannya dengan benar, jujur dan akurat. Konsep kepatuhan ini sesuai dengan pendapat Harinurdin (2009), bahwa kondisi ideal kepatuhan pajak didefinisikan sebagai keadaan suatu wajib pajak yang memenuhi semua kewajiban perpajakannya dan melaksanakan hak perpajakannya dalam bentuk formal dan kepatuhan material. Dengan demikian, kepatuhan pajak dapat didefinisikan sebagai menghitung pajak terutang yang harus dibayar dengan benar, memberikan laporan pajak tepat waktu, dan membayar pajak tanpa ada paksaan.

\section{Metoda Analisis Data}

\section{Uji Validitas dan Reliabilitas}

Uji validitas dalam penelitian ini menggunakan teknik korelasi product moment pearson test, yaitu mengkorelasikan skor item dengan skor total. Suatu item dinyatakan valid atau gugur, maka dilakukan perbandingan antara koefisien $r$ hitung dengan koefisien $r$ tabel. Jika $r$ hitung lebih besar dari $r$ tabel, maka item tersebut valid. Sebaliknya, apabila $\mathrm{r}$ hitung lebih kecil dari $\mathrm{r}$ tabel, berarti item tersebut tidak valid (Ghozali, 2005: 49).

Uji reliabilitas adalah pengujian untuk mengukur kehandalan kuesioner yang merupakan indikator dari variabel penelitian. Pengukuran dilakukan satu kali dan hasilnya dibandingkan dengan pernyataan lain untuk mengukur korelasi antar jawaban pernyataan. Suatu konstruk atau variabel dikatakan reliabel apabila nilai Cronbach Alpha lebih besar dari 0,600 (Nunnaly, 1960 dalam Ghozali, 2005: 46).

\section{Uji Asumsi Klasik}

\section{Uji Multikolinearitas}

Multikolinearitas adalah suatu keadaan antara variabel independen satu dengan yang lain terdapat hubungan/korelasi linier yang sempurna. Untuk mendeteksi ada atau tidaknya multikolinearitas dari suatu model regresi dilakukan dengan melihat nilai variance inflation factor (VIF). Jika VIF lebih besar dari 10, maka model regresi terdapat multikolinearitas (Kurniawati, 2006: 62). 


\section{Uji Autokorelasi}

Autokorelasi adalah hubungan antara data yang satu dengan data yang lain dalam satu variabel. Teknik pengujian yang digunakan adalah Durbin-Watson Test dengan mempertimbangkan jumlah variabel independen (k), tingkat kesalahan (alpha), dan jumlah data (n). Tingkat pengujian autokorelasi dapat diketahui berdasarkan tabel Durbin Watson dengan kriteria d lebih kecil dari dL: terdapat autokorelasi positif; dL lebih kecil dari d lebih kecil dari dU: ragu-ragu; dU lebih kecil dari d lebih kecil dari 4-dU: tidak terdapat autokorelasi; dan 4-dL lebih kecil dari d: terdapat autokorelasi negatif (Nugroho, 2011: 104).

\section{Uji Heteroskedastisitas}

Uji heteroskedastisitas dilakukan untuk menguji ketidaksamaan varian residual model regresi dari pengamatan satu dengan pengamatan yang lain. Cara yang digunakan adalah Spearman's rank correlation test, yaitu dengan mengkorelasikan variabel independen. Jika Spearman's rank sig. lebih besar dari 0,05 (alpha), maka model tersebut tidak heteroskedastisitas (Kurniawati, 2006: 63).

\section{Uji Normalitas}

Uji normalitas residual data dilakukan dengan uji statistik One Sample Kolmogorov Smirnov. Dasar pengambilan keputusan adalah jika nilai Asymp. Sig. (2-tailed) lebih kecil dari 0,05 (alpha), maka residual data tidak berdistribusi normal. Sebaliknya, jika nilai asymp. sig. lebih besar dari 0,05 (alpha), maka residual data berdistribusi normal (Kurniawati, 2006: 19).

\section{Analisis Regresi (Pengujian Hipotesis)}

\section{Koefisien Determinasi}

Koefisien determinasi (R2) mengukur kemampuan model regresi dalam menerangkan variasi variabel dependen. Nilai koefisien determinasi antara nol sampai satu $(1=100 \%)$. Jika nilai koefisien determinasi kecil, maka kemampuan variabel independen dalam menjelaskan variabel dependen persentasenya kecil. 


\section{Uji F}

Uji F pada dasarnya akan menunjukkan semua variabel independen yang digunakan dalam model regresi mempunyai pengaruh secara bersama-sama terhadap variabel dependen atau tidak. Hasil uji $\mathrm{F}$ dapat dilihat pada tabel ANOVA, apabila nilai signifikansi lebih besar dari 0,05, maka tidak terdapat pengaruh variabel independen secara bersama-sama terhadap variabel dependen dan apabila nilai signifikansi lebih kecil dari 0,05 , maka minimal terdapat salah satu variabel independen yang berpengaruh terhadap variabel dependen (Kurniawati, 2006: 57).

\section{Uji t}

Uji t menunjukkan pengaruh variabel independen secara individu dalam menerangkan variasi variabel dependen. Hasil uji $\mathrm{t}$ dapat dilihat pada tabel coefficients, apabila nilai signifikansi lebih besar dari 0,05 , maka tidak terdapat pengaruh variabel independen secara individu terhadap variabel dependen dan apabila nilai signifikansi lebih kecil dari 0,05 , maka terdapat pengaruh variabel independen secara individu terhadap variabel dependen (Kurniawati, 2006: 56).

\section{HASIL PENELITIAN DAN PEMBAHASAN}

Berdasar hasil penelitian ini, pada hipotesis pertama menunjukkan bahwa sikap tidak berpengaruh terhadap kepatuhan pajak badan dengan melihat tingkat signifikansinya 0,984 . Nilai signifikansinya $0,984>0,05$, maka hipotesis satu ditolak. Hal ini memberi bukti bahwa kuat atau lemahnya sikap dari tax professional tidak mempengaruhi tingkat kepatuhan pajak badan pada suatu perusahaan. Hasil ini berbeda dengan penelitian Mustikasari (2007) yang menyatakan bahwa sikap berpengaruh terhadap kepatuhan pajak badan. Hal ini disebabkan karena dalam penelitian ini tidak menggunakan kerangka teori perilaku.

Berdasar hasil penelitian ini, pada hipotesis kedua menunjukkan bahwa norma subjektif tidak berpengaruh terhadap kepatuhan pajak badan dengan melihat tingkat signifikansinya 0,145 . Nilai signifikansinya $0,145>0,05$, maka hipotesis dua ditolak. Hal ini memberi bukti bahwa lingkungan sosial yang meliputi teman, keluarga, konsultan pajak, petugas pajak, dan pimpinan perusahaan dari tempat tax professional bekerja tidak mempengaruhi kepatuhan pajak badan pada suatu 
perusahaan.

Hasil ini berbeda dengan penelitian Mustikasari (2007) yang memberikan bukti empiris bahwa norma subjektif berpengaruh signifikan terhadap kepatuhan pajak wajib pajak badan. Akan tetapi, hasil ini sekaligus dapat memberi gambaran bahwa tax professional yang diberikan amanat untuk menghitung, membayar, dan melaporkan pajak dari suatu perusahaan mempunyai dedikasi yang tinggi terhadap pekerjaannya (konsistensi yang tinggi - mempunyai pengaruh positif meskipun tidak signifikan). Pengaruh yang tidak signifikan menunjukkan bahwa niat seseorang tidaklah semata-mata dipengaruhi oleh norma subjektif dari orang-orang di sekelilingnya (Hidayat, 2010).

Berdasar hasil penelitian ini, pada hipotesis ketiga menunjukkan bahwa kewajiban moral tidak berpengaruh terhadap kepatuhan pajak badan dengan melihat tingkat signifikansinya 0,613 . Nilai signifikansinya $0,613>0,05$, maka hipotesis tiga ditolak. Hal ini memberi bukti bahwa kuat atau lemahnya kewajiban moral dari tax professional tidak mempengaruhi kepatuhan pajak badan pada suatu perusahaan. Hasil ini bertentangan dengan penelitian Mustikasari (2007) yang menyimpulkan bahwa kewajiban moral mempengaruhi kepatuhan pajak wajib pajak badan secara signifikan.

Jayanto (2011) mengatakan bahwa kewajiban moral merupakan norma individu yang dimiliki oleh seseorang, namun kemungkinan tidak dimiliki oleh orang lain. Kelompok wajib pajak yang masih berada pada tingkat moral yang rendah adalah wajib pajak yang pada umumnya memiliki tingkat pendapatan rendah, serta tingkat pendidikan yang rendah pula, sehingga pemenuhan kebutuhan fisik lebih penting dari pada kebutuhan sosial. Kelompok wajib pajak seperti ini umumnya terdapat di negara-negara sedang berkembang dengan tingkat pendapatan per kapita yang rendah. Negara-negara sedang berkembang menerapkan sanksi legal akan lebih bermanfaat daripada sanksi moral dalam meningkatkan kepatuhan pajak. Berbeda halnya dengan yang terjadi di negara maju, dengan tingkat pendapatan per kapita yang cukup tinggi. Kebutuhan fisik sudah bukan merupakan prioritas utama sehingga mereka lebih berorientasi pada kebutuhan sosial.

Berdasar hasil penelitian ini, pada hipotesis keempat menunjukkan bahwa 
niat berperilaku tidak berpengaruh terhadap kepatuhan pajak badan dengan melihat tingkat signifikansinya 0,155 . Nilai signifikansinya $0,155>0,05$ maka hipotesis empat ditolak. Hal ini memberi bukti bahwa kuat atau lemahnya niat berperilaku dari tax professional tidak mempengaruhi kepatuhan pajak badan pada suatu perusahaan.

Hasil ini berbeda dengan hasil penelitian Mustikasari (2007) dan Harinurdin (2009) yang memberikan bukti empiris bahwa niat berperilaku berpengaruh secara signifikan terhadap kepatuhan pajak badan. Akan tetapi, hasil ini sejalan dengan hasil dari tiga variabel sebelumnya, yaitu sikap; norma subjektif; dan kewajiban moral. Ketiga variabel tersebut merupakan faktor-faktor pembentuk niat berperilaku.

Berdasar hasil penelitian ini, pada hipotesis kelima menunjukkan bahwa kondisi keuangan perusahaan tidak berpengaruh terhadap kepatuhan pajak badan dengan melihat tingkat signifikansinya 0,265. Nilai signifikansinya 0,265 >0,05, maka hipotesis lima ditolak. Hal ini memberi bukti bahwa kuat atau lemahnya kondisi keuangan perusahaan tempat tax professional bekerja tidak mempengaruhi kepatuhan pajak badan dari suatu perusahaan. Hasil ini berbeda dengan penelitian Mustikasari (2007) dan Harinurdin (2009) yang menyimpulkan bahwa kondisi keuangan perusahaan berpengaruh positif dan signifikan terhadap kepatuhan pajak wajib pajak badan.

Jayanto (2011) mengatakan bahwa perusahaan yang mempunyai profitabilitas yang tinggi cenderung melaporkan pajaknya dengan jujur daripada perusahaan yang mempunyai profitabilitas rendah. Perusahaan dengan profitabilitas rendah pada umumnya mengalami kesulitan keuangan dan cenderung melakukan ketidakpatuhan pajak dengan harapan akan meningkatkan arus kasnya. Tekanan keuangan akan mempengaruhi pilihan metoda akuntansi. Hal ini berhubungan dengan pilihan pelaporan pajak. Hal ini menunjukan bahwa semakin tinggi tekanan keuangan yang dialami perusahaan semakin rendah tingkat kepatuhan tax professional dalam melaporkan pajak badannya.

Berdasar hasil penelitian ini, pada hipotesis keenam menunjukkan bahwa fasilitas perusahaan tidak berpengaruh terhadap kepatuhan pajak badan dengan 
melihat tingkat signifikansinya 0,666. Nilai signifikansinya 0,666 >0,05, maka hipotesis enam ditolak. Hal ini memberi bukti bahwa besar atau kecilnya fasilitas perusahaan tempat tax professional bekerja tidak mempengaruhi kepatuhan pajak badan dari suatu perusahaan. Tax professional hanya akan menjalankan tugasnya sesuai dengan kelengkapan administrasi pelaporan pajak yang ada. Hasil ini berbeda dengan penelitian Mustikasari (2007) dan Harinurdin (2009) yang menyatakan bahwa kepatuhan pajak badan dipengaruhi secara signifikan oleh fasilitas perusahaan.

Berdasar hasil penelitian ini, pada hipotesis ketujuh menunjukkan bahwa iklim organisasi berpengaruh terhadap kepatuhan pajak badan dengan melihat tingkat signifikansinya 0,000 . Karena nilai signifikansinya $0,000<0,05$, maka hipotesis tujuh diterima. Hal ini memberi bukti bahwa kuat atau lemahnya iklim organisasi tempat tax professional bekerja mempengaruhi kepatuhan pajak badan dari suatu perusahaan. Hasil penelitian ini mendukung penelitian yang dilakukan oleh Mustikasari (2007) dan Harinurdin (2009), bahwa iklim organisasi berpengaruh positif terhadap kepatuhan pajak badan

Hasil penelitian ini menunjukkan bahwa tax professional tidak berpengaruh besar terhadap tingkat kepatuhan pajak wajib pajak badan pada Perusahaan Industri Manufaktur Besar di Daerah Istimewa Yogyakarta Hal ini ditunjukkan dari tujuh variabel yang diteliti dengan objek penelitian tax professional, hanya satu variabel, yaitu iklim organisasi yang berpengaruh terhadap kepatuhan pajak badan.

\section{SIMPULAN, KETERBATASAN, DAN SARAN}

Penelitian ini menganalisis mengenai faktor-faktor yang mempengaruhi tingkat kepatuhan pajak wajib pajak badan perusahaan industri manufaktur besar di Daerah Istimewa Yogyakarta. Adapun variabel-variabel yang digunakan dalam penelitian ini meliputi 7 variabel independen yaitu ( sikap, norma subjektif, kewajiban moral, niat berperilaku, kondisi keuangan perusahaan, fasilitas perusahaan, dan iklim organisasi), serta variabel dependen yaitu kepatuhan pajak badan.

Berdasar hasil pengujian dan pembahasan pada bagian sebelumnya, maka 
simpulan dari penelitian ini sebagai berikut:

1. Hipotesis satu $\left(\mathrm{H}_{1}\right)$ ditolak yang menunjukkan bahwa sikap dari tax professional tidak berpengaruh terhadap kepatuhan pajak wajib pajak badan pada perusahaan manufaktur di Daerah Istimewa Yogyakarta.

2. Hipotesis dua $\left(\mathrm{H}_{2}\right)$ ditolak yang menunjukkan bahwa norma subjektif dari tax professional tidak berpengaruh terhadap kepatuhan pajak wajib pajak badan pada perusahaan manufaktur di Daerah Istimewa Yogyakarta.

3. Hipotesis tiga $\left(\mathrm{H}_{3}\right)$ ditolak yang menunjukkan bahwa kewajiban moral dari tax professional tidak berpengaruh terhadap kepatuhan pajak wajib pajak badan pada perusahaan manufaktur di Daerah Istimewa Yogyakarta.

4. Hipotesis empat $\left(\mathrm{H}_{4}\right)$ ditolak yang menunjukkan bahwa niat berperilaku dari tax professional tidak berpengaruh terhadap kepatuhan pajak wajib pajak badan pada perusahaan manufaktur di Daerah Istimewa Yogyakarta.

5. Hipotesis lima (H5) ditolak yang menunjukkan bahwa kondisi keuangan perusahaan tempat tax professional bekerja tidak berpengaruh terhadap kepatuhan pajak wajib pajak badan pada perusahaan manufaktur di Daerah Istimewa Yogyakarta.

6. Hipotesis enam ( $\left.\mathrm{H}_{6}\right)$ ditolak yang menunjukkan bahwa fasilitas perusahaan tempat tax professional bekerja tidak berpengaruh terhadap kepatuhan pajak wajib pajak badan pada perusahaan manufaktur di Daerah Istimewa Yogyakarta.

7. Hipotesis tujuh $\left(\mathrm{H}_{7}\right)$ diterima yang menunjukkan bahwa iklim organisasi perusahaan tempat tax professional bekerja berpengaruh terhadap kepatuhan pajak wajib pajak badan pada perusahaan manufaktur di Daerah Istimewa Yogyakarta.

Penelitian ini tidak terlepas dari keterbatasan-keterbatasan yang menjadi sebab penelitian ini menjadi bias. Keterbatasan penelitian ini yaitu persepsi tax professional yang antipati atau cenderung takut terhadap background peneliti, sebagai mahasiswa program studi akuntansi jurusan ekonomi, terlebih lagi mengetahui fokus penelitian mengenai perpajakan. Hal tersebut mengakibatkan proses pencarian data menjadi semakin lama dan kemungkinan berpengaruh besar terhadap hasil penelitian. 
Berdasar simpulan dan keterbatasan dalam penelitian ini, maka diajukan saran sebagai berikut:

1. Penelitian selanjutnya dapat mengembangkan penelitian mengenai faktor-faktor yang mempengaruhi kepatuhan pajak wajib pajak badan dengan objek jenis usaha yang lain, misal industri jasa dan dapat mencoba pada daerah lain yang berbeda.

2. Penelitian selanjutnya dapat menambah variabel-variabel baru dan menerapkan teori lain dengan menggunakan model penelitian yang berbeda dengan harapan dapat menghasilkan temuan yang lebih bermanfaat.

3. Penelitian ini dimanfaatkan untuk meningkatkan kepatuhan pajak wajib pajak badan di lingkungan perusahaan, bahwa iklim organisasi yang kondusif akan menjadi salah satu faktor yang mendorong kepatuhan pajak wajib pajak badan.

4. Pemerintah membuat kebijakan-kebijakan perpajakan yang efektif dan efisien, mensosialisasikan sistem perpajakan dan transparansi pemanfaatan pajak, serta meningkatkan pengetahuan pajak bagi seluruh rakyat Indonesia sehingga dapat meningkatkan kesadaran akan pentingnya membayar pajak.

\section{DAFTAR PUSTAKA}

Ajzen, Icek, 1991. "The Theory of Planned Behavior" Organizational Behavior and Human Decision Processes 50, hal. 179-211.

. 2002. Constructing a TPB Questionnaire: Conceptual and Methodological Considerations. September (Revised January, 2006).

Ardani, Mira Novana. 2010. Pengaruh Kebijakan Sunset Policy terhadap Kepatuhan Wajib Pajak (Studi Kasus di Kanwil Direktorat Jenderal Pajak Jawa Timur I Surabaya). Tesis. Semarang: Universitas Diponegoro.

Badudu, J.S, dan Sutan Mohammad Zain. 1994. Kamus Umum Bahasa Indonesia. Jakarta: PT. Inter Grafika.

Bobek, Donna D. dan Richard C. Hatfield. 2003. "An Investigation of Theory of Planned Behavior and the Role of Moral Obligation in Tax Compliance". Behavioral Research in Accounting Vol. 15, hal. 13-38. 
Brotodihardjo, Santoso. 1993. Pengantar Ilmu Hukum Pajak. Bandung: PT. Refika Aditama

Dajan, Anto. 1986. Pengantar Metoda Statistik. Jilid II. Jakarta: PT. Pustaka LP3ES.

Ghozali, Imam. 2005, Analisis Multivariate dengan Program SPSS, Edisi Ketiga, Semarang: Badan Penerbit Universitas Diponegoro.

Harinurdin, Erwin. 2009. "Perilaku Kapatuhan Wajib Pajak Badan". Jurnal Ilmu Administrasi dan Organisasi Vol. 16, No. 2 (Mei-Agustus), hal. 96-104.

Hendry. 2012. Menentukan Ukuran Sampel [Online]. Didapatkan: http://teorionline.net/menentukan-ukuran-sampel-menurut-para-ahli [03> Januari 2014].

Hidayat, Widi dan Argo Adhi Nugroho. 2010. "Studi Empiris Theory of Planned Behavior dan Pengaruh Kewajiban Moral pada Perilaku Ketidakpatuhan Pajak Wajib Pajak Orang Pribadi”. Jurnal Akuntansi dan Keuangan Vol. 12, No. 2, hal. 82-93.

Hutagaol, John, Wing Wahyu Winarno dan Arya Pradipta. 2007. "Strategi Meningkatkan Kepatuhan Wajib Pajak". Akuntabilitas Vol. 6, No. 2 (Maret), hal. 186-193.

Jayanto, Prabowo Yudo. 2011. "Faktor-faktor Ketidakpatuhan Wajib Pajak "Jurnal Dinamika Manajemen Vol. 2, No. 1 (Maret), hal. 48-61.

Jogiyanto. 2004. Metodologi Penelitian Bisnis: Salah Kaprah dan PengalamanPengalaman. Edisi 2004/2005. Yogyakarta: BPFE UGM.

Kartawan dan Dedi Kusmayadi. 2002. "Pengaruh Persepsi Wajib Pajak Badan Mengenai Undang-Undang Pajak Penghasilan terhadap Pelaksanaan Sistem Self Assessment pada BUMS dan BUMD Kantor Pelayanan Pajak Tasikmalaya". Jurnal Ekonomi \& Bisnis Jilid 7, No. 2, hal. 1-9.

King, Laura A. 2010. Psikologi Umum: Sebuah Pandangan Apresiasi. Terjemahan oleh Brian Marwensdy. Jakarta: Salemba Humanika.

Kuncoro, Mudrajad. 2001. Metoda Kuantitatif: Teori dan Aplikasi untuk Bisnis dan Ekonomi. Yogyakarta: UPP AMP YKPN. 
Kurniawati, Indah. 2006. Modul Pengolahan Data Elektronik: Mengolah Data Statistik dengan SPSS 11.5. Yogyakarta: Universitas Ahmad Dahlan.

Mardiasmo. 2009. Perpajakan. Yogyakarta: Penerbit Andi.

Martowardojo, Agus. 2012. Menteri Keuangan: Realisasi Tax Ratio 2011 Naik Satu Persen [Online]. Didapatkan:

<http://www.pajak.go.id/content/menteri-keuangan-realisasi-tax-ratio2011-naik-satu-persen [03> Februari 2012].

Munandar, Anshar Sunyoto. 2001. Psikologi Industri dan Organisasi. Jakarta: UI Press.

Mustikasari, Elia. 2007. "Kajian Empiris tentang Kepatuhan Wajib Pajak Badan di Perusahaan Industri Pengolahan di Surabaya". Simposium Nasional Akuntansi X, hal. 1-42.

Nugroho, Yohanes Anton. 2011. It's Easy. Olah Data dengan SPSS. Yogyakarta: Skripta Media Creative.

Patria, Bhina. 2009. Analisis Data dengan SPSS [Online]. Didapatkan: $<$ http://inparametric.com [25> Maret 2012].

Rachmany, A. Fuad. 2012. Dirjen Pajak: Penerimaan Pajak 2011 Capai 99,3 Persen [Online]. Didapatkan: <http://www.pajak.go.id/content/dirjenpajak-penerimaan-pajak-2011-capai-993-persen [03> Februari 2012].

Rafiudin, Rahmat dan Asep Saepudin. 2009. Praktek Langsung SPSS 17. Jakarta: PT. Elex Media Komputindo.

Rakhmat, Jalaluddin. 1996. Psikologi Komunikasi. Surabaya: Remaja Rosdakarya.

Rustiyaningsih, Sri. 2011. Faktor-Faktor yang Mempengaruhi Kepatuhan Wajib Pajak Badan Widya Warta No. 2, Tahun XXXV (Juli), hal. 44-54.

Setiawan, Nugraha. 2007. Penentuan Ukuran Sampel Memakai Rumus Slovin dan Tabel Krejcie-Morgan: Telaah Konsep dan Aplikasinya. Makalah disampaikan pada Diskusi Ilmiah Jurusan Sosial Ekonomi Fakultas Peternakan Universitas Padjajaran, Bandung. 
Soemitro, Rachmat. 1988. Asas dan Dasar Perpajakan 1, Cetakan 3. Bandung: PT. Eresco.

Somang, M. Rais. 2006. Analisis Faktor-Faktor yang Mempengaruhi Tingkat Kepatuhan Wajib Pajak Badan di Kabupaten Serang. Tesis. Jakarta : Universitas Indonesia. Tidak dipublikasikan.

Sugiyono. 2011. Metoda Penelitian Kombinasi (Mixed Methods). Bandung: CV. Alfabeta.

Suhendra, Euphrasia Susy. 2010. "Pengaruh Tingkat Kepatuhan Wajib Pajak Badan terhadap Peningkatan Penerimaan Pajak Penghasilan Badan" Jurnal Ekonomi Bisnis Vol. 15, No. 1 (April), hal. 58-65.

Supriyati dan Nur Hidayati. 2008. "Pengaruh Pengetahuan Pajak dan Persepsi Wajib Pajak terhadap Kepatuhan Wajib Pajak Badan” Jurnal Akuntansi dan Teknologi Informasi Vol. 7, No. 1 (Mei), hal. 41-50.

Waluyo dan Wirawan B. Ilyas. 2000. Perpajakan Indonesia. Jakarta: Penerbit Salemba Empat. 